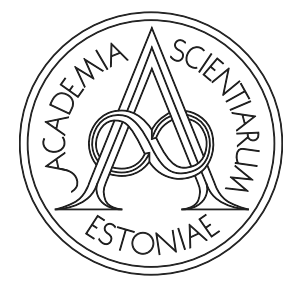

Proceedings of the Estonian Academy of Sciences, $2021,70,4,407-412$

https://doi.org/10.3176/proc.2021.4.06

Available online at www.eap.ee/proceedings

MANUFACTURING

ENGINEERING

\title{
Modern robot-integrated manufacturing cell according to the needs of Industry 4.0
}

\author{
Madis Moor ${ }^{\mathrm{a}, \mathrm{b}^{*}}$, Kristo Vaher ${ }^{\mathrm{a}, \mathrm{b}}$, Jüri Riives ${ }^{\mathrm{b}}$, Tavo Kangru ${ }^{\mathrm{a}}$ and Tauno Otto ${ }^{\mathrm{b}}$ \\ a Institute of Technology, TTK University of Applied Sciences, Pärnu mnt 62, 10135 Tallinn, Estonia \\ ${ }^{\mathrm{b}}$ Department of Mechanical and Industrial Engineering, Tallinn University of Technology, Ehitajate tee 5, 19086 Tallinn, Estonia
}

Received 17 June 2021, accepted 16 July 2021, available online 2 November 2021

(C) 2021 Authors. This is an Open Access article distributed under the terms and conditions of the Creative Commons AttributionNonCommercial 4.0 International License (http://creativecommons.org/licenses/by-nc/4.0/).

\begin{abstract}
The continuous need to develop Industry 4.0 branches has led to a position where highly sophisticated and multi-layer smart robotic systems are guiding the way to future manufacturing. This study aims to build a connectivity and system intelligent layer on top of a co-bot integrated Computer Numerical Control (CNC) based manufacturing cell. The connectivity layer is used to bypass all the data collected from machines to the upper intelligent layer and vice versa. When raw data arrives in the intelligent layer, it will be converted to information and again to knowledge for reflection to be sent back to the cell. Machine-to-Machine Communication and Digital Twin process for optimization are used for data conversions. This study is a downscale example of the Cyber-Physical System (CPS) for further development of the existing robot cells.
\end{abstract}

Key words: Industry 4.0, industrial robot, co-bot, modern manufacturing.

\section{INTRODUCTION}

The combination of technologies, such as Smart Sensors, Internet of Things (IoT) [1], Machine-to-Machine Communication (M2M) [2], and Artificial Intelligence (AI) based solutions have fundamental importance in the process of further development of the existing manufacturing cells. The next phase for production units in the future is to implement the data collecting level as criteria for decision-making possibilities for the existing robot cells. This can be achieved by using virtual environments for data processing and management of the actual robot cell. In this article, possible solutions and methods are investigated for upgrading the existing production cells to the level of automation and intelligence needed for Industry 4.0 (I4.0).

The goal was to define possibilities of how to develop the existing production system to meet the needs of I4.0

\footnotetext{
${ }^{*}$ Corresponding author, madis.moor@tktk.ee
}

principles by applying Smart Sensor technology. The information was collected, processed, and controlled by the Manufacturing Execution System (MES) [3] to ensure continuous workflow in every production unit as a whole system.

\section{ONTOLOGY OF MODERN MANUFACTURING}

Knowledge-based economy and production is characterized by continuously shortening product life cycles, but continuously increasing demands towards products' functionality, quality, and other customers' requirements. The orientation towards development and improvement of the production system and its efficient use is extremely important. A company is an entire system that operates in a certain location and customer-oriented field of activity. A company may belong to a group or network, whereby its belonging to the network may be either abstract or having certain connections or functions with the network [4]. 
The production system has certain resources, processes, and strategies (Fig. 1). The production system is characterized by the physical environment (number, type, layout, and location) and functional environment that is expressed by technological possibilities of machine tools. Machine tools have mutual logistical relations inside the system as well as relations with the external environment. Technological possibilities of a company's production system evolve mainly based on machinery (CNC tools, Industrial Robots (IRs) and Co-bots, presses, welding equipment, etc.). Technological possibilities can be defined as a set of characteristics of the current device for producing a specified workpiece or performing a certain technological task.

The industrial production of the future will be characterized by strong individualization of products under the conditions of highly flexible production, extensive integration of customers and business partners in valueadded processes. Future manufacturing combines technology, knowledge, information, and human ingenuity to develop and apply manufacturing intelligence. It comprises the smart use of networked information for demand-dynamic economics such as: integrated enterprise and supply chain as well as broad-based workforce engagement; industrial robots that work safely with people in shared spaces; and metal-based additive manufacturing. Driven by the software connected to the Internet, the real and virtual worlds are growing closer and closer together to form the IoT.
In this article, we focus mainly on the workplace level, by which we mean a robotic workplace, and view it as an integration of different hardware and software tools forming a Cyber-Physical System (CPS) (Fig. 2). CPS is based on a multi-dimensional complex space that generates and evolves diverse subspaces to contain different types of individuals interacting with, reflecting, or influencing each other directly or through the cyber physical subspace. CPSs are engineered systems that are built from and depend upon the synergy of computational and physical components.

Three main functionalities for modern robot-cells are: - Internet of Things,

- Machine-to-Machine Communication,

- Big Data.

IoT gives the possibility to connect more devices to a central controller. This setup allows manufacturers to gather more data, also to streamline and digitize their processes more efficiently. With M2M the success of data exchange and autonomous automation would be achieved, and it depends on the machines' ability to communicate and their real-time responses with one another. The role of data and information is currently increasing in manufacturing. The extended supply chain, as well as horizontal and vertical value streams are based on data exchange and information processing. Thanks to IoT, data transfer possibilities, data analytics, different decision-making algorithms, AI possibilities can be used in the workplace for intelligent manufacturing with adaptive control, agile planning and real-time management.

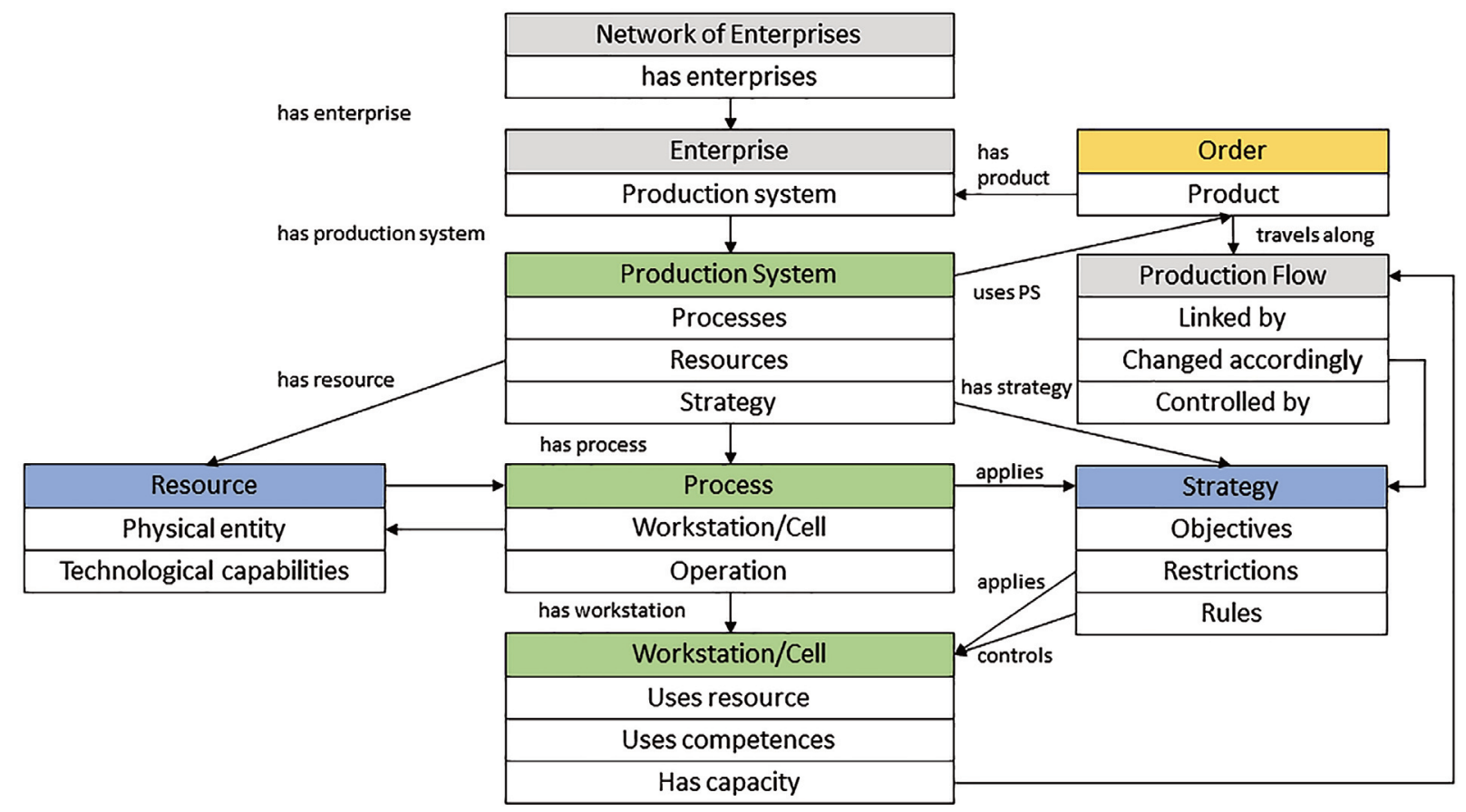

Fig. 1. Ontology in manufacturing [4]. PS - Production System. 


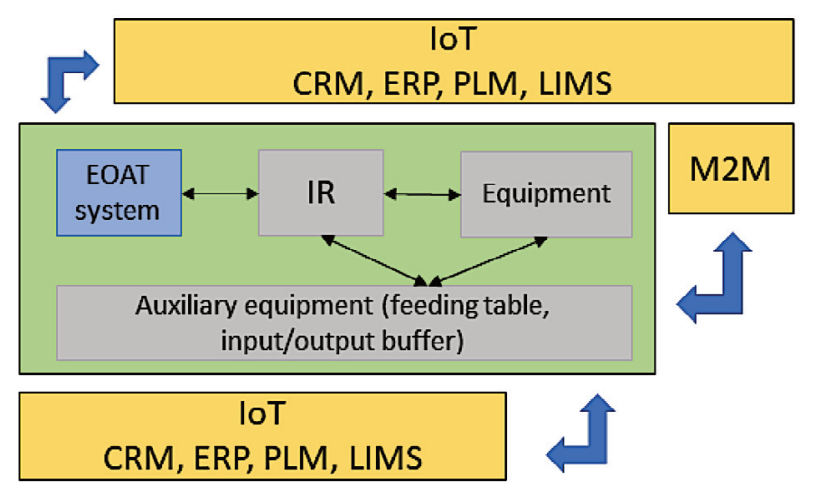

Fig. 2. Robot cell with CPS functionality. CRM - Customer Relations Management; ERP - Enterprise Resource Planning; PLM - Product Lifecycle Management; LIMS - Laboratory Information Management System; EOAT - End-of-Arm Tooling.

\section{INTEGRATION AND CONNECTIVITY}

The new manufacturing architecture follows the need to integrate vertical and horizontal value chains. As the production is becoming more intensive, more digital solutions (ERP, PLM, MES, CAD/CAM/CAQ, etc.) in both value chains are implemented into the general computing architecture trends. Over time smaller computers and PCs have distributed functions over networks, and distributed computing has been refined in many ways with Service
Oriented Architecture, HTTP, Remote Procedure Call (RPC), and other functions.

This integration and connectivity are formalized with the ISA-95.00-xx standard [5]. Traditionally, ISA-95 has been implemented in a 5-layer system network architecture, implying that each level only communicates through adjacent levels (Fig. 3). This implementation was built around the technology available at the time it was conceived, which has changed significantly with high power computers, high-performance networking, and embedded edge computing, all supported by more sophisticated and refined software that has been developed for general computing [6].

The technical innovation of Industry 4.0 towards smart manufacturing is characterized by the integration of manufacturing systems, using digital twin principles in the different value chain positions, virtual reality and augmented reality in designing and execution stages, big data, and data analytics for continuous improvement.

\section{INTEGRATED MANUFACTURING IMPLEMENTATION}

In this article, we have focused on the implementation of miniature production system which has been under development at TTK University of Applied Sciences (Fig. 4). The equipment and component description was explained

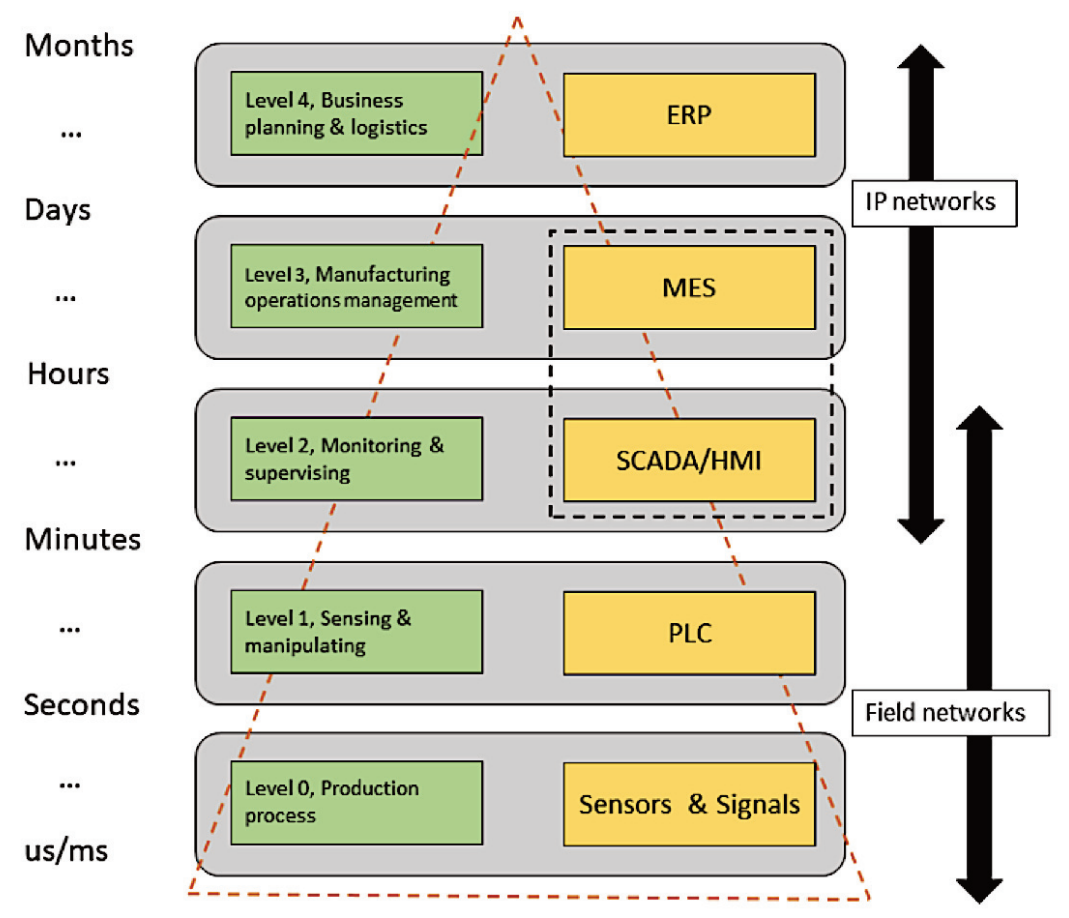

Fig. 3. Integration and connectivity in manufacturing according to ISA-95.00 [6]. SCADA - System Control and Data Acquisition; HMI - Human-Machine Interface; PLC - Product Life Cycle. 


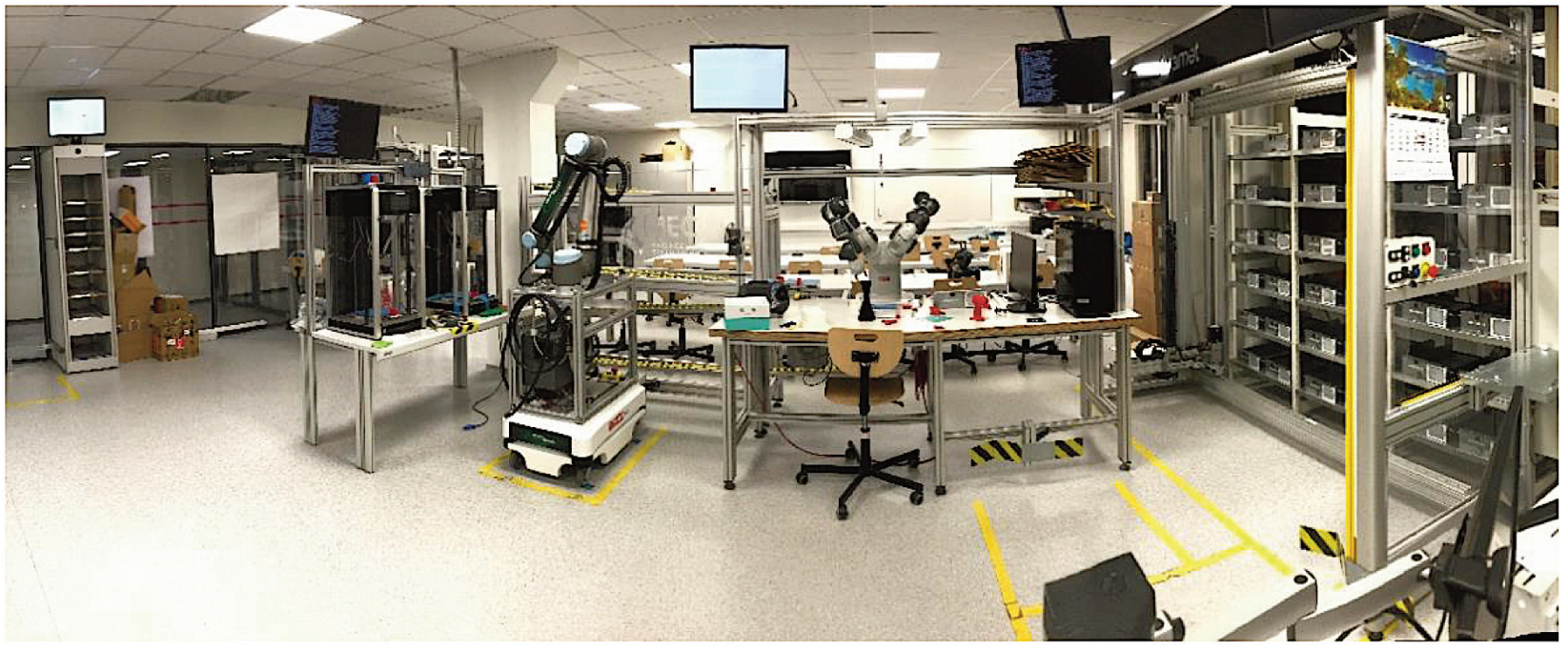

Fig. 4. TTK Industry 4.0 CPS.

in [7], and the multi-layer CPS implements similar ontology of manufacturing as stated above (Fig. 1).

The entire system works autonomously, where incoming orders are planned in the ERP system, M2M communication and the sequence of production operations is managed by a program created at the MES level. All devices in the system are connected to MES via LAN or Wi-Fi but are independent of each other and do not require constant communication with a higher-level program (Fig. 5). All the units are programmed for each operation, and the MES program distributes only start commands and waits for execution confirmation to distribute new commands. Error reports from devices are forwarded to MES where necessary decisions are made for further operations. According to

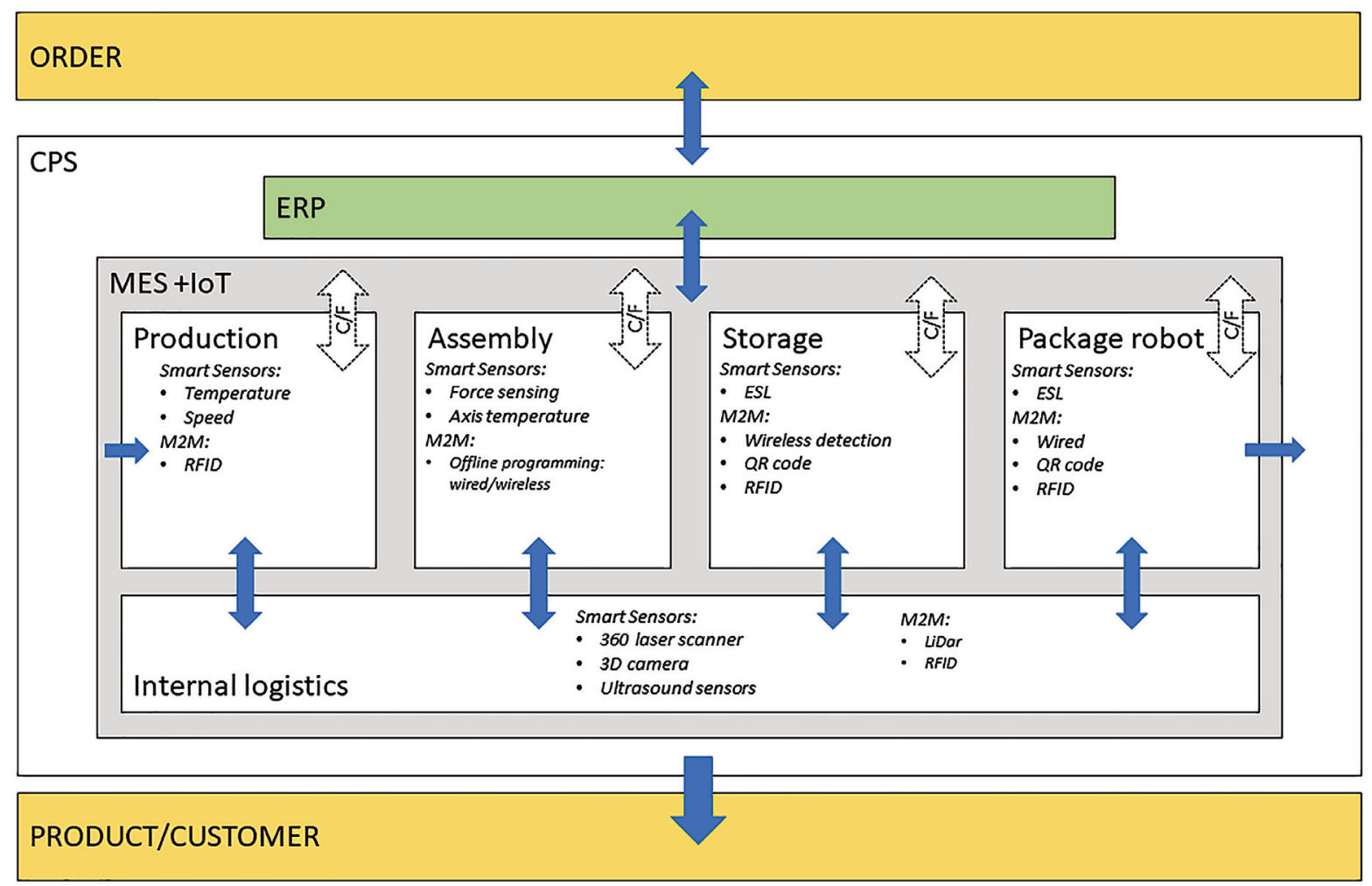

Fig. 5. Developed system's schematic diagram. ESL - Electronic Shelf Label; RFID - Radio Frequency Identification. 
the number of details needed to produce, MES is capable of evaluating unused workstations and decide how to produce similar items or details in parallel.

The system design is flexible and easy to reconfigure according to I4.0 principles, with the possibility to add new production equipment to the entire system without the need to make major changes to the control system. The mobile robot arm plays a major role in this factory, which enables to apply a similar method in the existing factory without making major adjustments for the robots. Each unit is equipped with photoelectric sensors (PNP output) [8] to monitor and give feedback about the current situation at the workplace - first of all to PLC and then to MES for the management of other units. Another important part of CPS is RFID technology [9] with the RFID chip [10], reader [11], communication module, and power module. Each production plate and storage box are equipped with an RFID chip and every unit, including MES, has live information.

\section{CONCLUSIONS}

Modern manufacturing has been changing rapidly in the last decade. The sophisticated and multi-layered robotintegrated manufacturing is not in distant future. Our entrepreneurs have the machinery and equipment to manufacture products according to the customer needs, but the continuously shortening product life cycle and the product's increasing complexity forces us to raise the efficiency of the existing system. In this paper, we have reviewed the possibilities of applying I4.0 principles to the existing downscaled IR and co-bot based manufacturing system, by using Smart Sensors and M2M connectivity combined with IoT based manufacturing software. Our study indicates that the usage of I4.0 technologies is strictly based on the needs, and the purpose is to raise the efficiency of certain robot-based manufacturing cells.

\section{ACKNOWLEDGEMENTS}

We thank our colleagues from TalTech, IMECC and TTK UAS who provided insight and expertise that greatly assisted the research. The publication costs of this article were covered by the Estonian Academy of Sciences and Tallinn University of Technology.

\section{REFERENCES}

1. Batth, R. S., Nayyar, A. and Nagpal, A. Internet of robotic things: Driving intelligent robotics of future - concept, architecture, applications and technologies. In Proceedings of the 2018 4th International Conference on Computing Sciences (ICCS), Jalandhar, India, August 30-31, 2018. IEEE, 2019, 151-160. https://doi.org/10.1109/ICCS.2018. 00033

2. Stojmenovic, I. Machine-to-Machine communications with in-network data aggregation, processing, and actuation for large-scale cyber-physical systems. IEEE Internet Things $J$., 2014, 1(2), 122-128. https://doi.org/10.1109/JIOT.2014.231 1693

3. Saenz de Ugarte, B., Artiba, A. and Pellerin, R. Manufacturing execution system - a literature review. Prod. Plan. Control, 2009, 20(6), 525-539. https://doi.org/10.1080/ 09537280902938613

4. Lõun, K., Riives, J. and Otto, T. Framework for extended use of technological resources in the network of enterprises. In Proceedings of the 7th International DAAAM Baltic Conference "Industrial Engineering", Tallinn, Estonia, April 22-24, 2010. TTU Press, 316-321.

5. ANSI/ISA-95.00-xx. Enterprise Control System Integration.

6. Lydon, B. (ed.). ISA-95 in the IoT and digitalization era. www.automation.com (accessed 2020-01-06).

7. Vaher, K., Vainola, V. and Otto, T. Industry 4.0 laboratory. Industry 4.0, technological basis of "Industy 4.0". In 1/5: Proceedings of the IV International Scientific Conference, Industry 4.0. Summer session, Burgas, Bulgaria, June 24-27, 2019. Industry 4.0, Sofia, 52-53.

8. Omron Corporation. Photoelectric sensor E3F1-DP22. https://industrial.omron.eu/en/products/E3F1-DP22 (accessed 2021-01-24).

9. Want, R. An introduction to RFID technology. IEEE Pervasive Comput., 2006, 5(1), 25-33. https://doi.org/10.1109/MPRV. 2006.2

10. Siemens Corporation. RFID chip MDS D124. https://mall. industry.siemens.com/mall/en/WW/Catalog/Products/10047 932 (accessed 2021-01-24).

11. Siemens Corporation. RFID reader RF340R (GEN2). https:// support.industry.siemens.com/cs/pd/467302?pdti=pi\&dl=en $\& \mathrm{lc}=\mathrm{en}-\mathrm{GB}$ (accessed 2021-01-24). 


\title{
Tööstus 4.0 printsiipidel põhinev moodne ja integreeritud tootmisjaoskond
}

\author{
Madis Moor, Kristo Vaher, Jüri Riives, Tavo Kangru ja Tauno Otto
}

Tehnoloogia areng koos Tööstus 4.0 printsiipidega on suunanud meid olukorda, kus kõrgelt arenenud ja mitmekihilised intelligentsed robotsüsteemid näitavad teed tulevikku. Artiklis on välja toodud, kuidas arendada ühilduvust eri üksuste vahel. Tootmisüksus põhineb TTK Tööstus 4.0 labori baasil ja tööstusrobotite, koostöörobotite ja CNC-seadmete baasil ning seadmete omavaheline infojagamise mudel on eeskujuks tööstuslike rakenduste arendamisel. Ühilduvuse kiht süsteemis on vajalik info kogumiseks eri üksustelt, info töötlemiseks ja otsuste vastuvõtmiseks. Selle tarbeks on vajalik kasutada kombinatsiooni eri tehnoloogiatest, nagu targad sensorid, asjade internet (IoT) ja masinatevaheline suhtlus (M2M), mis tagab kiire infoedastamise ning andmete optimeerimisvõimalused. Uuringu tulemustest selgub, et Tööstus 4.0 printsiipidel põhinev moodne tootmisjaoskond on tugevalt seotud vajaduste ja eesmärkidega, et tõsta olemasoleva robottootmise efektiivsust. 